\title{
Announcements
}

\section{National Conference on the Use of On-Line Computers in Psychology}

The Tenth National Conference on the Use of On-Line Computers in Psychology will meet at Washington University in St. Louis, Missouri, on Wednesday, November 12, 1980. Gene Levinson of Washington University, Department of Psychology, is Local Arrangements Chairman. The Conference meets for a full day prior to the meetings of the Psychonomic Society, held November 13-15 at the Chase-Park Plaza Hotel in St. Louis. The meetings of the Computer Conference are open to anyone interested in the uses and applications of computers. Student registrations are encouraged. Information concerning membership and the Conference may be obtained from Cynthia Null, Department of Psychology, College of William and Mary, Williamsburg, Virginia 23185.

\section{Nominations for Editorships}

Nominations are being solicited for the Editorships of Memory \& Cognition and Physiological Psychology, for a 4-year term to begin January 1, 1982. Nominations (including self-nominations) should be sent to the address below for forwarding to the Publications Committee of the Governing Board. It is expected that appointment of each Editor will be made by January 1981 .

Send nominations to:

\author{
James G. Greeno \\ Learning Research and Development Center \\ University of Pittsburgh \\ 3939 O'Hara Street \\ Pittsburgh, Pennsylvania 15260
}

\section{Special Issue of Physiological Psychology}

The June 1980 issue of Physiological Psychology was devoted to the publication of papers from a symposium on The Role of the Hippocampus in Learning and Memory, which was held at Williamstown, Massachusetts, June 1979. Single copies of this issue are available at \$6 each from the Publications Office, Psychonomic Society, Inc., 2904 Guadalupe Street, Austin, Texas 78705. 